\title{
ENHANCING OF FLEXURAL STRENGTH OF WEB OPENING REINFORCED GEOPOLYMER BEAMS BY USING FRP STRIPS
}

\author{
"Oday H. Abbas ${ }^{1}$
}

Hesham A.Numan ${ }^{1}$

1) Civil Engineering Department, College of Engineering, Mustansiriyah University, Baghdad, Iraq

\begin{abstract}
This study is devoted to inspect the flexural behavior of Geopolymer reinforced concrete beams with "large" web transverse opening and strengthened by three kinds of Fiber Reinforced Polymer materials. The implemented experimental program comprised casting eight beams under static and "one stage" repeated load, two of these are normal concrete beams and the others are Geopolymer beams. These beams are divided into two groups, the first comprised four beams of solid and beams "with transvers web opening" under static load for normal and Geopolymer concrete beams. The second group are of four Geopolymer beams that one of them is "un strengthened and having transvers web opening" while the others are also have transvers web opening but strengthened by different kinds of Fiber Reinforced Polymer materials sheets that installed vertically aligned and accompanied with the $90 \mathrm{~mm}$ diameter large circular web opening. The strengthening materials included are Carbon Fiber Reinforced Polymer, Glass fiber Reinforced Polymer and Hybrid (one layer of Glass + one layer of Carbon) reinforced polymer sheets. The results showed that for the ultimate load capacity was decreased by 9.96\% for holed normal concrete beam if compared with solid normal concrete solid beam while such capacity was decreased $2.25 \%$ and $11.89 \%$ for solid and holed Geopolymer beams respectively. In addition to that, the maximum load capacity is also decreased by $8.16 \%$, $10.20 \%$ and $12.25 \%$ for Glass, Carbon and Hybrid fiber reinforced polymer strengthened beams if compared with reference beams "holed un strengthened beam" subjected to cyclic load.
\end{abstract}

Keywords: Flexural response; large web openings; FRP; Repeated load; Concrete type; GFRP and GFRP

\section{Introduction}

As a structural element, the RC beams may subject to repeated loads during its life which may cause failure due to fatigue strength lack. Grossly, in order to overcome the drawback of the presence of transversal openings, strengthening the existing (RC) beams is an essential issue for enhancing the relevant structural performance. To do the role of such strengthening, the Fiber Reinforced Polymer (FRP) sheets can be used by installing it at the existing zone of opening.

On the other hand, Geopolymer concrete is consisted from the reaction of the raw materials that having aluminosilicate with alkaline solution. So, many substances may be used for manufacturing Geopolymer like rice husk ash, slag, Metakaolin, Fly Ash ...etc. In this research Metakaolin is used for Geopolymer concrete production because it is availability in Iraq as a local material [3].

It is known that one ton of carbon dioxide $\left(\mathrm{CO}_{2}\right)$ is emitted to the environment by manufacturing one ton of Portland cement and this means that, (6-7) \% of global carbon dioxide emissions are generated from cement production [1]. In many

*Corresponding Author: Odayh2021@gmail.com 
cases and circumstances, the reinforced concrete (RC) beams have constructed with transversal openings for delivering pipes of air conditioning devices, sanitary pipes, ducts and water supply pipes. Such presence dictates a pivotal shortcoming represented by the lack in flexural rigidity [2].

Many reasons are considered for using Metakaolin for manufacturing Geopolymers: it is available in large quantities, it has homogeneous properties, in addition Metakaolin is considered environmentally friendly as compared with cement. The calcination temperature for production of Metakaolin is less than Portland cement and Metakaolin emits from $80-90 \%$ less $\mathrm{CO}_{2}$ than cement (coming from combustion only) [4].

The presence of transversal openings is dictated by the need for passing the service pipes within reinforced concrete structures. In general, the structural response of $\mathrm{RC}$ beams is affected negatively by the presence of such openings in term of the high levels of consequent deflection and cracking [5].

More precisely, the web openings located in the $\mathrm{RC}$ beams may be vary in its form. However, many shapes such as rectangular, square, triangular, and many others are examined throughout the literature of this field and the rectangular form is the most common shape in current practice [6]. In addition, Web openings can be found where the shear zone of the column support intersects the beam [7].

In contrast, it's believed throughout the literature that the need for classifying the beam web opening is important because it is governs the structural behavior as a whole [9]. Additionally, such importance because the pivotal wondering about the existence of the beam theory according to that classification.
In addition, the "four - hinge mechanism" is an approach than can usually interprets the failure in $\mathrm{RC}$ beams with opening when Vierndeel action is assumed [10]. According to some published recent contributions [12], the size of the reinforced concrete beam openings can be classified into "large" and "small".

In general, there are many trends in external strengthening of RC beams with opening, however, it can be distinguished that the wrapping around the opening using the FRP sheets as well as the steel plates strengthening has the vast majority of interest. The FRP trends have many advantages against others like the corrosion resistance and the good degree of improvement due to the good mechanical properties of that materials $[13,14,15,16]$.

In the final view, the research programs are still have motivations to examine any new possible FRP sheets fashions and propose the needed recommendations.

\section{Recent Contributions}

\subsection{FRP Solid Reinforced Concrete Beams}

Imam et al., (2004) [17] deduced that the addition of Carbon Fiber Reinforced Polymer (CFRP) enhances ultimate capacity for both shear and flexural strength design beams according to the used strengthening fashion. Another efforts showed that CFRP sheets enhances the consequent shear strength as proved by AlAmery and Al-Mahaidi, (2005) [18]. Some research proved that CFRP strengthened RC beams have a good durability against humid environment as stated by Grace, (2005) [19].

Dash (2009) [20] showed that the using if GFRP is also effective in RC beams flexural strengthening and may vary mode of failure from flexural to shear. A noticeable compatibility was noticed between the level of strengthening and 
the stiffness and consequent ultimate strength in CRFP strengthening as shown by Sobuz et al., (2011) [21].

Önal, (2014) [22] found that the CFRP strengthening have a clear excellency against GFRP with respect to flexural ultimate strength.

By using the Finite element approach, Kadhim et al. (2019) [23] demonstrated that the ultimate load capacity increased by $14.8 \%$ despite $20 \%$ corrosion in the flexural steel reinforcement with eight strata of Basalt-FRP material and underneath wrapping style.

\subsection{FRP Reinforced Concrete Beams with Web Opening}

It is agreed throughout the recent contributions that the presence of large opening causes a consequent lack in the flexural rigidity and the FRP strengthening can play a good role in recovering the lost capacity as proved by some experimental programs like Abdalla et al., (2003) [24]. Some of the intended scientific research was devoted to introduce numerical modeling to such problem and a reasonable amount of agreement was gained against physical modeling as mentioned by Chin et al., (2012) [25].

Chakrasali and Abdulla, (2015) [26] deduced that the strengthening with CFRP sheets around the opening is more efficient than strengthening inside that opening.

Finally, it is proved that the best way to strengthen RC beams with opening is the $\mathrm{U}$ wrapping and jacketing as proposed and deduced by Nie et al., (2020) [27].

\section{Significance of the Study}

Grossly, proper implementation of geopolymer reinforced concrete beams in civil engineering projects is very governing issue especially with the presence of large openings. In this way, reliable testing results of such type of structural elements is very important to build a comprehensive understanding to the intended structural response.

Consequently, research organizations and authors have many reasons to be motivated to understand and quantify RC Geopolymer beams behavior under repeated load, therefore, this study is an attempt to develop the knowledge about this field by applying and experimental program.

\section{Experimental Program}

\subsection{Beam Details}

Eight reinforced normal and Geopolymer concrete beams that were casted with dimensions of $120 \mathrm{~mm}$ width and $190 \mathrm{~mm}$ total height and total length of $1400 \mathrm{~mm}$. The specimens included two un strengthened normal concrete beam specimens, one solid beam that would subjected to static load and the other have circular opening of $90 \mathrm{~mm}$ in diameter and subjected also to static load. Three Geopolymer un strengthened beams, one of them is solid and subjected to static load while the other have circular hole of $90 \mathrm{~mm}$ in diameter and subjected also to static load, the third Geopolymer beam have the same circular opening subjected to repeated load. Such beam is established as a base point to compare with other proposed FRP strengthening fashions. The remaining three specimens are Gopolymer beams conducted to characterize the proposed FRP techniques within this experimental program. Each one of the solid and holed beams are reinforced with $2 \varphi 10 \mathrm{~mm}$ top and bottom. In addition, stirrups of $\varphi 6$ mm was used @ 80 mm spacing for $400 \mathrm{~mm}$ near supports, $160 \mathrm{~mm}$ around the central circular opening and $120 \mathrm{~mm}$ between central and supports region as shown in Fig. (1 a). In addition, the cross section of each beam is viewed in Fig. (1 b). Accordingly, Table 
(1) shows the designation of the tested beams. The strengthening fashion during the current study is the "vertical strips" as shown in Fig. (2).

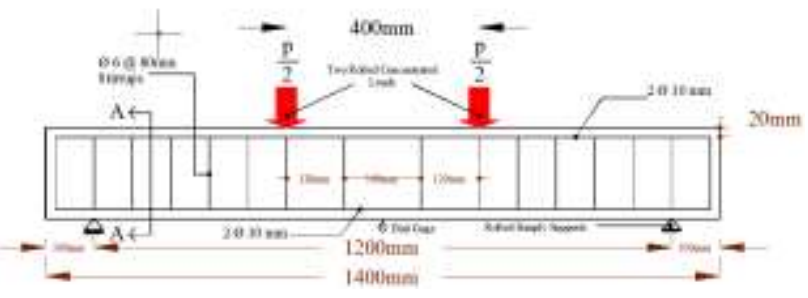

(a)

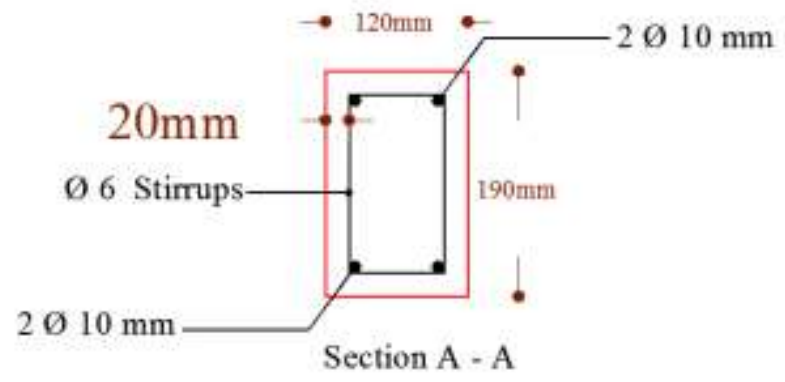

(b)

Figure 1. Beams setup and reinforcement arrangement

Table 1. Beams details

\begin{tabular}{|c|c|}
\hline $\begin{array}{c}\text { Beam } \\
\text { designation }\end{array}$ & Description \\
\hline NSS & $\begin{array}{l}\text { Normal concrete solid beam subjected } \\
\text { to static load }\end{array}$ \\
\hline NOS & $\begin{array}{l}\text { Normal concrete opened beam } \\
\text { subjected to static load }\end{array}$ \\
\hline GSS & $\begin{array}{l}\text { Geopolymer concrete solid beam } \\
\text { subjected to static load }\end{array}$ \\
\hline GOS & $\begin{array}{l}\text { Geopolymer concrete opened beam } \\
\text { subjected to static load }\end{array}$ \\
\hline GOR & $\begin{array}{l}\text { Geopolymer concrete opened beam } \\
\text { subjected to repeated load }\end{array}$ \\
\hline GORSG & $\begin{array}{l}\text { Geopolymer concrete opened beam } \\
\text { subjected to repeated load } \\
\text { strengthened by "Glass fibers Vertical } \\
\text { strips" }\end{array}$ \\
\hline GORSH & $\begin{array}{l}\text { Geopolymer concrete opened beam } \\
\text { subjected to repeated load } \\
\text { strengthened by "Hybrid fibers } \\
\text { Vertical strips" which are consisted of } \\
\text { one layer of (CFRP + GFRP) }\end{array}$ \\
\hline GORSC & $\begin{array}{l}\text { Geopolymer concrete opened beam } \\
\text { subjected to repeated load } \\
\text { strengthened by "Carbon fibers } \\
\text { Vertical strips" }\end{array}$ \\
\hline
\end{tabular}
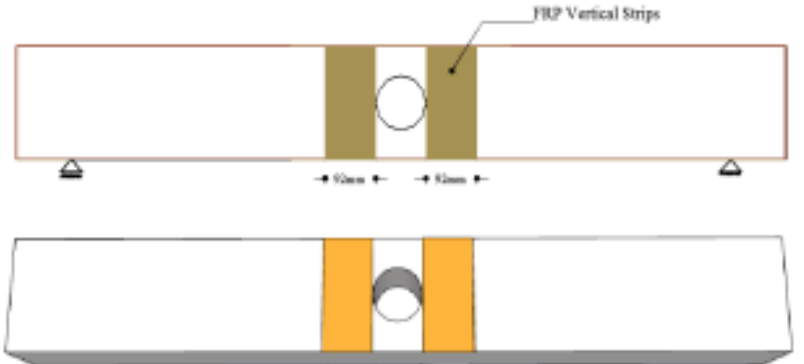

Figure 2. Vertical strips fashion

\subsection{Materials}

\subsubsection{Cement}

The Type I of Portland cement was used to form normal concrete of group one which coincides Iraqi standard specification No. 5, 1984 [28].

\subsubsection{Fine Aggregate}

The used sand in this study coincides Iraqi specification No.45, 1984 [29].

\subsubsection{Coarse Aggregate}

The washed coarse aggregate that wholly used in the present study with maximum size of $10 \mathrm{~mm}$ which coincides Iraqi specification No.45, 1984 [29].

\subsubsection{Metakaolin}

Iraq's kaolin clay was brought from the Ministry of industry and minerals / State Company for mining industries / Department of mineral extraction which produced in the Dewekhla area in Govemorate of Al-Ramadi, Iraq, which used for producing Metakaolin was used. Kaolin was crushed by air blowing and calcined in a furnace at $750 \pm 20{ }^{\circ} \mathrm{C}$ for 2 hours and the Metakaolin was cooled at room temperature for 24 hours.

\subsubsection{Sodium Hydroxide ( $\mathrm{NaOH}$ )}

The local market commercial Sodium Hydroxide Solid Flakes that were 98 percent pure and packed in $25 \mathrm{~kg}$ sealed containers was used within this study. The solvent of sodium hydroxide liquid is first set by dissolving the 
$\mathrm{NaOH}$ flakes in the distilled water to prepare the alkaline solution.

\subsubsection{Sodium Silicate $\left(\mathrm{Na}_{2} \mathrm{SO}_{3}\right)$}

In the local market, sodium silicate or (glass water) is commercially available for industrial use. $\mathrm{Na}_{2} \mathrm{SiO}_{3}$ is a dense, sticky liquid that is clear to off white in color. The water content of the sodium silicate was $55 \%$ by mass.

\subsubsection{Water}

The traditional tap water was used.

\subsubsection{Steel Reinforcement}

Deformed bars with $10 \mathrm{~mm}$ diameter were used as tensile and compressive longitudinal reinforcement. Deformed steel bars with $6 \mathrm{~mm}$ was kept @ $80 \mathrm{~mm}$ for $400 \mathrm{~mm}$ in each side if supports and decreased to @ 120 mm between supports zones and the region of central holes (for opened specimens) and @ $160 \mathrm{~mm}$ in the central region of opening. The tensile test was carried out for each bar type with length $(500 \mathrm{~mm})$, these bars were tested under tensile force using a hydraulic tensile testing system with power $(1000 \mathrm{kN})$, the results are shown in Table (2).

Table 2. Tensile test of reinforcement bar

\begin{tabular}{cccc}
\hline Nominal Diameter (mm) & & 10 & 6 \\
\cline { 1 - 1 } Actual Diameter (mm) & 9.95 & 5.92 \\
\cline { 1 - 1 } Yield Stress (Fy) (MPa) & 520 & 615 \\
\cline { 1 - 1 } Ultimate Strength (fu) & & 645 & 710 \\
\hline
\end{tabular}

\subsection{The FRP Properties}

The mechanical properties of the FRP materials that used for this study are presented in Table 3.
Table 3. Mechanical properties of the FRP materials

\begin{tabular}{ccc}
\hline FRP materials & $\begin{array}{c}\text { Young's } \\
\text { Modulus } \\
(\mathrm{GPa})\end{array}$ & $\begin{array}{c}\text { Ultimate tensile } \\
\text { strength }(\mathrm{MPa})\end{array}$ \\
\hline Carbon & 260 & 3330 \\
\hline Glass & 70 & 3150 \\
\hline
\end{tabular}

\subsection{Molds Fabrication}

Plywood molds are prepared to enable casting the fourteen beams test specimens. The sides were fixed by brass hinged size 3 inch and the plywood thickness is $(16 \mathrm{~mm})$. Before casting the walls of molds, was coated with an oil coating so as to prevent the adhesion between molds and concrete.

\subsection{Mix Deign for Geopolymer Concrete}

A trail mix was initially tested to obtain the optimal design proportions for all experimental work, for this study, one Geopolymer concrete mix was used in this investigation from three trial mixes who depend on the molarity of $\mathrm{NaOH}$ with different concentrations as required. Then 3 cubes of size $(10 \times 10 \times 10) \mathrm{mm}$ were casted in three layers for each concentration of sodium hydroxide. A tamping rope with a diameter of 20 $\mathrm{mm}$ was used to compress the growing sheet.

In addition, by using a trowel, the top surface was raised during mortar compaction and the borders of the mold were softly tapped to remove air within the mortar. After 24 hours of casting, all cubes were removed from molds and then positioned to sun curing then placed in room temperature until the test. Details of Geopolymer mix are given in Table (4). All specimens casted with nominal cube compressive strength (30 $\mathrm{MPa})$ in 28 days. 
Table 4. Mix proportion of gropolymer concrete

\begin{tabular}{cc}
\hline Quantity in a cubic meter & Details \\
\hline Metakaolin (kg) & 400 \\
\hline Sand(kg) & 720 \\
\hline Gravel (kg) & 1100 \\
\hline Alkaline solution (lit.) & 180 \\
\hline Water (lit.) & 40 \\
\hline
\end{tabular}

\subsection{Producing Normal Portland Cement Concrete}

The conducted dry mix contents of the normal Portland concrete cement are coarse aggregate, fine aggregate, and cement with mix proportions shown in Table (5) to give normal compressive strength of $32 \mathrm{MPa}$.

Table 5. Mix properties of normal concrete

\begin{tabular}{cccc}
\hline $\begin{array}{c}\text { Cement } \\
\left(\mathbf{k e} / \mathbf{m}^{3}\right)\end{array}$ & $\begin{array}{c}\text { Sand } \\
\left(\mathbf{k g} / \mathbf{m}^{3}\right)\end{array}$ & $\begin{array}{c}\text { Gravel } \\
\left(\mathbf{k g} / \mathbf{m}_{3}\right)\end{array}$ & $\begin{array}{c}\text { Water/ } \\
\text { cement } \\
\text { w/c Ratio }\end{array}$ \\
\hline 350 & 700 & 1400 & 0.43 \\
\hline
\end{tabular}

\subsection{Mixing Procedure for Geopolymer Concrete}

Geopolymer mortar casting is similar to cement mortar casting in which a dry mixture of metakaolin and sand as well as gravel was created in a $50 \mathrm{~kg}$ capacity pot, and then the alkaline solution and water are added and mixed for 2 to $5 \mathrm{~min}$ to give a regular mix. The fresh metakaolin-based Geopolymer mortar was found to be viscous, compact and light in color. For the cement concrete mixtures, additional mixing time of around two minutes was provided to ensure homogeneity. The rectangular molds were filled in three layers after mixing, then completely assembled on a vibrating table to eliminate any trapped air.

\subsection{Strengthening Procedure}

First of all, the specimens were taken mechanical grinding by suitable grinding commercial sheets to get good smoothness. Then after, the beams were cleaned by air compressor to remove the duct that can be accumulated on specimens. "Sikadur 330" Epoxy was used as an adhesive material "using a laboratory spatuala" to do the under coating before installing any FRP sheet. The FRP sheets were then installed and established by suitable roller in order to avoid any possible entrapped air. Then after, the over coating by the same adhesive material was done and the FRP sheets surfaces were finished. For hybrid specimen, the procedure was repeated another time to do the required strengthening.

\subsection{Testing Machine}

All beams are tested by using by using the Uniaxial Testing Machine with ultimate load capacity of $3000 \mathrm{kN}$, the steel frame, consisting of two parts; loading arm and supporting frame, the loading arm consisting of IPE300 steel section. The support frame consists of four C100 welded together to obtain a rigid support, steel rod of diameter (25) mm welded at the top of the frame to obtain a roller boundary condition, as shown on the Fig. 3 The load was applied slowly in increments of $5 \mathrm{kN}$ until static failure and the load was applied for each repeating at intervals of $2.5 \mathrm{kN}$, until load failure. The "one cycle - two steps" fashion of repeated load was done during this experimental program which is surveyed and followed by some recent contributions [30]. It is worth to mention that the boundary conditions of all beam specimens were simply supported.

\subsection{Testing Procedure for Beams}

The load was directed towards the support on two points every $400 \mathrm{~mm}$ away from the middle of the beam. The dial gages of at least $0.01 \mathrm{~mm}$ were 
used to measure the deflections below the load points and to measure the deflection at the mid span. The readings on the dial gauge were reported at different loads. A multi-channel (strainmeter) recording of steel strains. The load was placed at $2.5 \mathrm{kN}$ increments and the repeated load was applied in "two monotonic one cycle steps", the first at $17.5 \mathrm{kN}\left(55 \% \mathrm{P}_{\mathrm{u}}\right)$ and the other at $25 \mathrm{kN}$. The first crack was recognized using vision and for respective load increments the deflections and strain values were recorded until failure. The beams failure mode was also reported, and the reading and recording of the maximum crack width was observed.

\section{Results and Discussion}

\subsection{First Crack Load, Yield Load, and Ultimate Strength}

Table (6) shows first crack load, yield load, and ultimate strength within the current study, within the group one, it can be recognized that the first crack load decreased by $16.67 \%, 8.33 \%$ and 25 $\%$ for NOS, GSS, and GOS respectively. In the other hand, the relevant yield load decreased by $23.2 \%, 23.1 \%$ and $23 \%$ for the same set of specimens as well as reduction in ultimate load strength by $9.96 \%, 2.25 \%$ and $11.89 \%$.

In the beams with openings, the decrees can be attributed to the presence of the large opening which reveals a noticeable decrease in flexural rigidity. On the other hand, the flexural rigidity of the Geopolymer beams is less than those of normal concrete in both solid and opened beams due to the mechanical properties of Geopolymer used.

In group two, it can be recognized that the first crack load increased by $8.16 \%, 10.20 \%$ and $12.25 \%$ for GORSG, GORSC and GORSH respectively if compared with GOR (un strengthened beam). In the other hand, the relevant yield load increased by $0.43 \%, 0.86 \%$ and $1.71 \%$ for the same set of specimens as well as increase in ultimate load strength by $1.09 \%$, $2.92 \%$ and 5.47 .

More precisely, such increase in strengthened beams can be attributed to the additional mechanical potential that added to the reinforced Geopolymer concrete beams. It is obvious that such increase in that levels is related to the general inherent stiffness and characteristics of the proposed FRP materials. So, the load limits (first cracking, yielding and ultimate load) arranged in a manner starting from glass - fiber to carbon fiber till hybrid.

Table 6. First crack load, yield load, and ultimate strength within the current study

\begin{tabular}{|c|c|c|c|c|}
\hline \multicolumn{5}{|c|}{ Group one } \\
\hline $\begin{array}{c}\text { Beam } \\
\text { designation }\end{array}$ & NSS & NOS & GSS & GOS \\
\hline $\begin{array}{c}\text { Cracking } \\
\text { load } \mathrm{P}_{\mathrm{cr}}(\mathrm{kN})\end{array}$ & 6 & 5 & 5.5 & 4.5 \\
\hline $\begin{array}{c}\text { Decrease in } \\
\mathrm{P}_{\mathrm{cr}} \%\end{array}$ & I & 16.67 & 8.33 & 25 \\
\hline $\begin{array}{l}\text { Yield load } \mathrm{P}_{\mathrm{y}} \\
(\mathrm{kN})\end{array}$ & 25.4 & 23.2 & 23.1 & 23 \\
\hline $\begin{array}{c}\text { Decrease in } \\
\mathrm{P}_{\mathrm{y}} \%\end{array}$ & I & 8.66 & 9.05 & 9.45 \\
\hline $\begin{array}{c}\text { Ultimate } \\
\text { load } \mathrm{Pu}(\mathrm{kN})\end{array}$ & 31.1 & 28 & 30.4 & 27.4 \\
\hline $\begin{array}{c}\text { Decrease in } \\
\mathrm{P}_{\mathrm{u}} \%\end{array}$ & I & 9.96 & 2.25 & 11.89 \\
\hline \multicolumn{5}{|c|}{ Group two } \\
\hline $\begin{array}{c}\text { Beam } \\
\text { designation }\end{array}$ & GOR & GORSG & GORSC & GORSH \\
\hline $\begin{array}{c}\text { Cracking } \\
\text { load } \mathrm{P}_{\mathrm{cr}}(\mathrm{kN})\end{array}$ & 4.9 & 5.3 & 5.4 & 5.5 \\
\hline $\begin{array}{c}\text { Increase in } \\
\mathrm{P}_{\mathrm{cr}} \%\end{array}$ & I & 8.16 & 10.2 & 12.25 \\
\hline $\begin{array}{l}\text { Yield load } \mathrm{P}_{\mathrm{y}} \\
(\mathrm{kN})\end{array}$ & 23.1 & 23.2 & 23.4 & 23.8 \\
\hline $\begin{array}{c}\text { Increase in } \\
\mathrm{P}_{\mathrm{y}} \%\end{array}$ & I & 0.43 & 0.86 & 1.71 \\
\hline $\begin{array}{c}\text { Ultimate } \\
\text { load } \mathrm{Pu}(\mathrm{kN})\end{array}$ & 27.4 & 27.7 & 28.2 & 28.9 \\
\hline $\begin{array}{c}\text { Increase in } \\
\mathrm{P}_{\mathrm{u}} \%\end{array}$ & I & 1.09 & 2.92 & 5.47 \\
\hline
\end{tabular}

\subsection{Load - Deflection Relationship}

Table (7) shows a comparison between the proposed specimens for both groups with respect 
to the yield deflection, ultimate deflection, and ductility ratio for the proposed specimens within this group. In group one, it can be noticed from the figure that the load - deflection curves consists of three parts, the first part is linear elastic until the first crack load, the second portion began beyond the elastic stage until yielding tensile reinforcement steel, and final portion is the stage after yielding of tensile steel reinforcement until the beam failure. The effect on deflection becomes clear depending on the extent of the reduction in the concrete. However, the relevant yield deflection increased by $20 \%$, $4 \%$ and $40 \%$ for NOS, GSS and GOS if compared with the reference beam "NSS" while the ultimate deflection increased by $2.89 \%$, $3.62 \%$ and $4.35 \%$ respectively.

In addition, Fig. (3 a) shows the load - mid span deflection curves for NSS, NOS, GSS and GOS respectively. It can be reported from such figure that NOS, GSS and GOS illustrated slightly lower stiffness than the NSS, while the ductility ratio levels were increased for strengthened specimens and report 5.52, 4.73, 5.5 and 4.11 for NSS, NOS, GSS and GOS respectively.

It can be noticed that the difference between the specimens become obvious after the yielding stage for beams with opening because the cracks have been extended to cover the web opening area in opposite to the case before yielding stage.

In group two, It can be noticed from the figure that the load - deflection curves consists of five parts, the first part is linear elastic until the first crack load, the second stage is the "first monotonic step of load at $17.6 \mathrm{kN}$ ", the third stage between the first step and the yielding load limit. The fourth stage is the "second monotonic of load at $25 \mathrm{kN}$ " while the last stage is begun after the second monotonic step of load till failure of Geopolymer beams.
However, the relevant yield deflection decreased by $11.27 \%, 7.17 \%$ and $20 \%$ for GORSG, GORSC and GORSH respectively if compared with GOR (un strengthened specimen). On the other hand, ultimate deflection decreased by $7.14 \%, 5.06 \%$ and $1.39 \%$ for the same sequence of specimens above .

In addition, Fig. ( 4 b) shows the load - mid span deflection curves for GOR, GORSG, GORSC and GORSH. It can be reported from such figure that GORSG, GORSC and GORSH illustrated better stiffness than the GOR, while the ductility ratio levels were increased for strengthened specimens and report 5.03, 5.32, 6.41, for GORSG, GORSC and GORSH respectively.

It is recognized that the resulted ductility ratio arrangement affected by yielding and ultimate deflection levels. It can be also noticed that the difference between the specimens become obvious after the yielding stage for beams with opening because the cracks have been extended to cover more area.

Table 7. Yield deflection, ultimate deflection, and ductility ratio for both groups

\begin{tabular}{|c|c|c|c|c|}
\hline \multicolumn{5}{|c|}{ Group one } \\
\hline $\begin{array}{l}\text { Specimens } \\
\text { designation }\end{array}$ & NSS & NOS & GSS & GOS \\
\hline Yield & & & & \\
\hline $\begin{array}{c}\text { deflection } \Delta y \\
(\mathrm{~mm})\end{array}$ & 2.5 & 3 & 2.6 & 3.5 \\
\hline $\begin{array}{c}\text { Decrease in } \Delta y \\
\%\end{array}$ & I & 20 & 4 & 40 \\
\hline $\begin{array}{c}\text { Ultimate } \\
\text { deflection } \Delta \mathrm{u} \\
(\mathrm{mm})\end{array}$ & 13.8 & 14.2 & 14.3 & 14.4 \\
\hline $\begin{array}{c}\text { Increase in } \\
\Delta \mathrm{u} \%\end{array}$ & / & 2.89 & 3.62 & 4.35 \\
\hline $\begin{array}{c}\text { Ductility ratio } \\
\Delta \mathrm{u} / \Delta \mathrm{y}\end{array}$ & 5.52 & 4.73 & 5.5 & 4.11 \\
\hline \multicolumn{5}{|c|}{ Group two } \\
\hline $\begin{array}{l}\text { Specimens } \\
\text { designation }\end{array}$ & GOR & $\begin{array}{c}\text { GORS } \\
\text { G }\end{array}$ & $\begin{array}{c}\text { GORS } \\
\mathrm{C}\end{array}$ & $\begin{array}{c}\text { GORS } \\
\mathrm{H}\end{array}$ \\
\hline $\begin{array}{c}\text { Yield } \\
\text { deflection } \Delta y \\
(\mathrm{~mm})\end{array}$ & 3.46 & 3.07 & 2.85 & 2.28 \\
\hline
\end{tabular}




\begin{tabular}{ccccc}
\hline $\begin{array}{c}\text { Decrease in } \Delta \mathrm{y} \\
\%\end{array}$ & $/$ & 11.27 & 7.17 & 20 \\
$\begin{array}{c}\text { Ultimate } \\
\text { deflection } \Delta \mathrm{u} \\
(\mathrm{mm})\end{array}$ & 14.42 & 15.45 & 15.15 & 14.62 \\
$\begin{array}{c}\text { Increase in } \\
\Delta \mathrm{u} \%\end{array}$ & $/$ & 7.14 & 5.06 & 1.39 \\
$\begin{array}{c}\text { Ductility ratio } \\
\Delta \mathrm{u} / \Delta \mathrm{y}\end{array}$ & 4.17 & 5.03 & 5.32 & 6.41 \\
\hline
\end{tabular}

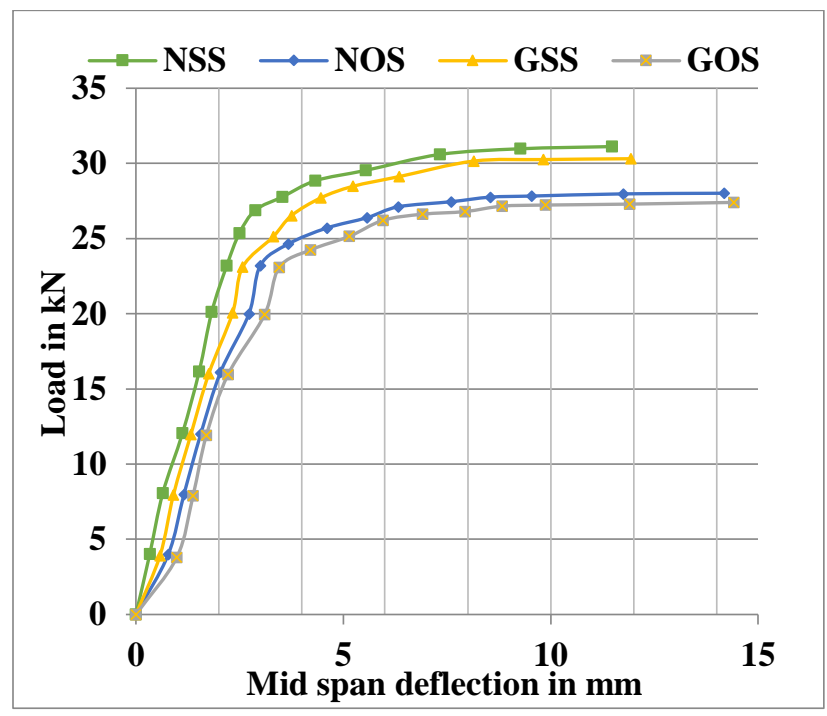

(a)

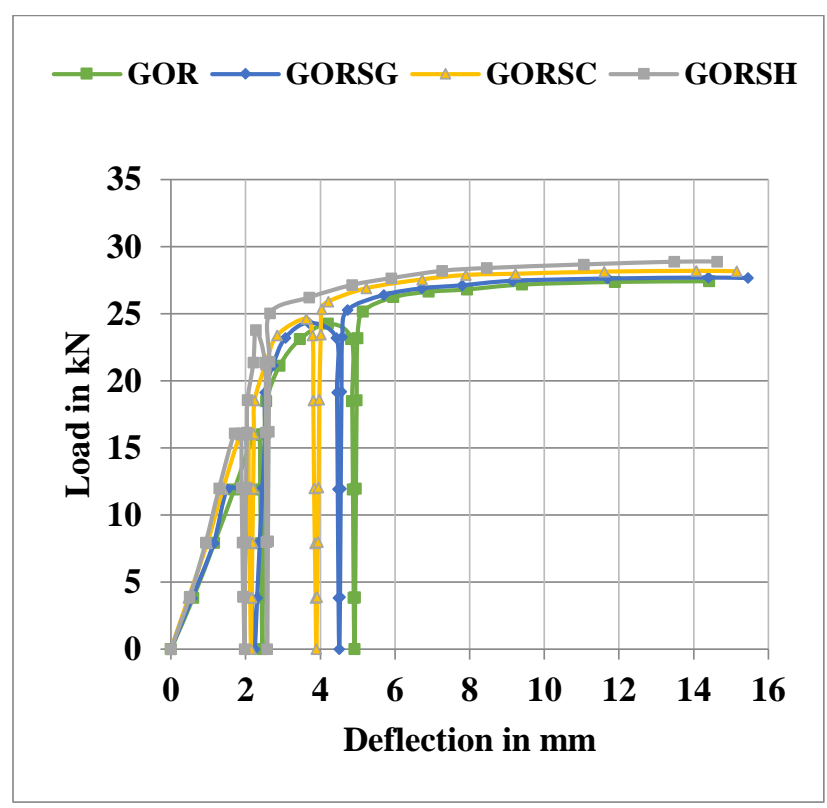

(b)

Figure 3. Load deflection curves: (a) Group one (b) Group two

\subsection{Load Strain Diagrams}

Table (8) and Fig. (4) show a comparison between the proposed specimens within for both groups with respect to concrete compressive strain and steel tensile strain. In the first group, it can be distinguished that the load tension steel strain diagram comprises three distinct stages; the first one is recognized in the region before the first crack limit when the effect of web opening is very slight for both types of concrete. The second stage is monitored after such limit till the yielding when the effect of web opening is visible. The third stage begins beyond the yielding of steel reinforcement and the diversity in strain between specimens is so clear till failure. Furthermore, it is noticed that the loadcompression concrete strain includes two legible stages. Also, it can be noted that the effect of the web opening is slight in the early stages of loading, but it begins to increase with the increasing of the load until failure. It is reported that the concrete strain at yield increased by $14.98 \%, 7.66 \%$ and $22.8 \%$ for NOS, GSS and GOS respectively if compared with NSS specimen (normal concrete solid beam) while ultimate concrete strain $31.14 \%, 31.06 \%$ and $31.82 \%$ for the same sequence above. On the other hand, yielding steel strain was also slightly increased by $0.05 \%, 0.99 \%$ and $1.29 \%$ and the ultimate steel strain increased by $4.82 \%, 3.43 \%$ and $6.50 \%$. The reason behind the increase in concrete compressive strain in both normal and Geopolymer beams is the stress concentration in the remaining concrete section.

In group two, it can be recognized that the load tension steel -strain diagram comprises five distinct stages; the first one is distinguished in the zone before first crack limit when the effect of strengthening does not have significant role. The second stage is the "first load monotonic step at $17.5 \mathrm{kN}$ ", the third is begun after the first release 
till yielding while the fourth is "the second load step at $25 \mathrm{kN}$. The last stage begins after the second step and the diversity in strain between specimens is clear till failure.

Furthermore, it is noticed that the load compression concrete strain includes also five stages. The first stage is linear part before the first monotonic load step, the second is the "first load step", the third is begun after first load step till (concrete strain at yield), the fourth begins after such limit till the second load step. The last stage begins after the second load step till failure .

It is reported that the concrete strain at yield decreased by $3.79 \%, 5.15 \%$ and $12.87 \%$ for GORSG, GORSC and GORSH if compared with GOR (un strengthened specimen) while ultimate concrete strain increased by $7.70 \%, 6.32 \%$ and $3.24 \%$ for the same specimen sequence above. Additionally, yielding steel strain was also slightly decreased by $0.05 \%, 0.25 \%$ and $0.45 \%$ and the ultimate steel strain increased by $10.96 \%$, $6.84 \%$ and $6.16 \%$.

It is noticed that the load strain results illustrate some kind of compatibility with load deflection results and ensure the mechanical properties differences between the proposed FRP materials. However, it is believed also that further research is needed to investigate the degree of correlation between the yield deflection and the consequent yield strain and concrete strain at yield.

Table 8. Comparison with respect to the concrete compressive strain and steel tensile strain values for both

\begin{tabular}{ccccc}
\multicolumn{5}{c}{ groups } \\
\hline \multicolumn{5}{c}{ Group one } \\
\hline Beam designation & NSS & NOS & GSS & GOS \\
\hline $\begin{array}{c}\text { Concrete strain at } \\
\text { Yield Ey } \times 10000 \\
\text { Increase in } \\
\begin{array}{c}\text { Concrete strain at } \\
\text { Yield Ey \% }\end{array}\end{array}$ & 6.01 & 6.91 & 6.47 & 7.38 \\
$\begin{array}{c}\text { Ultimate concrete } \\
\text { strain Eu } \times 10000\end{array}$ & 29.86 & 31.14 & 31.06 & 31.82 \\
\hline
\end{tabular}

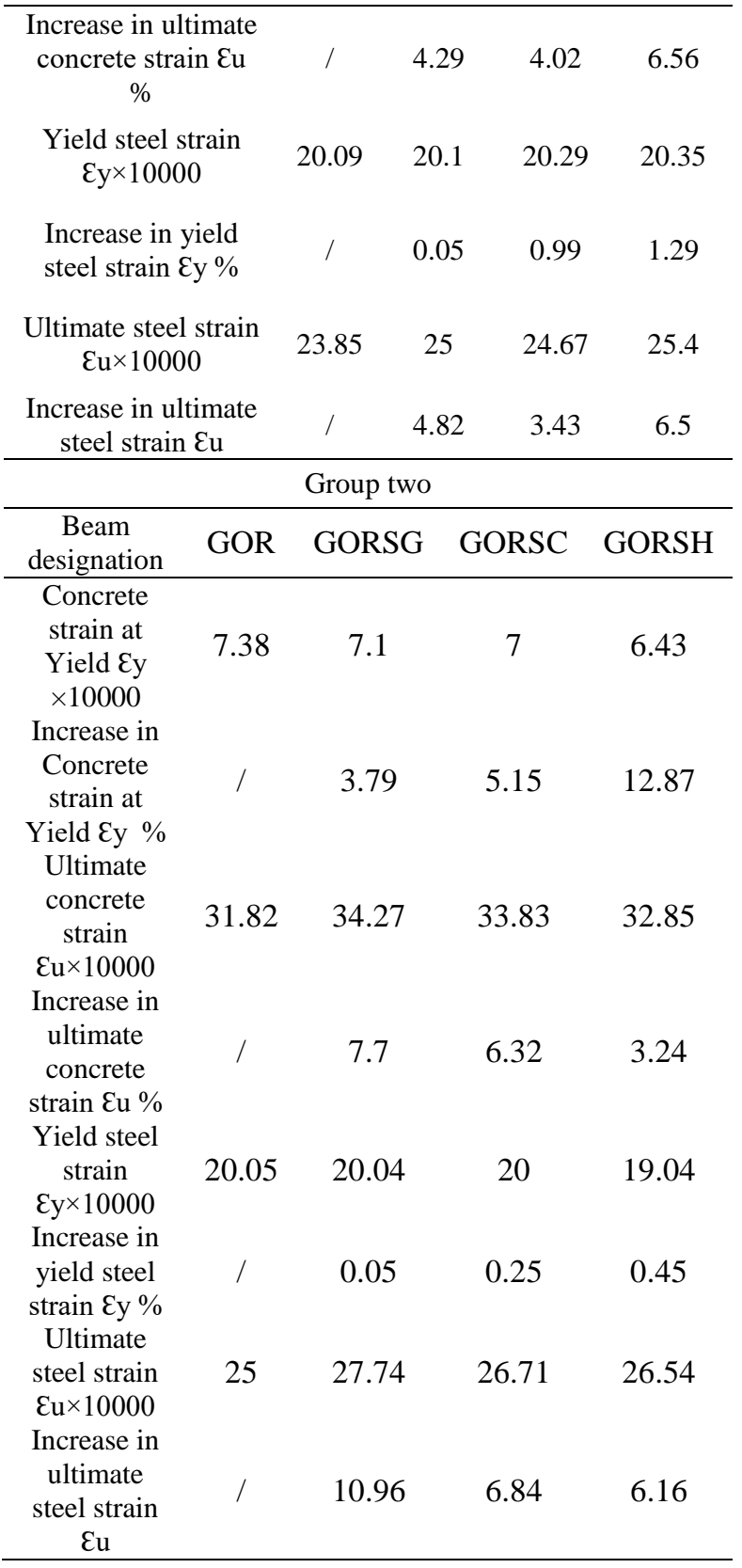




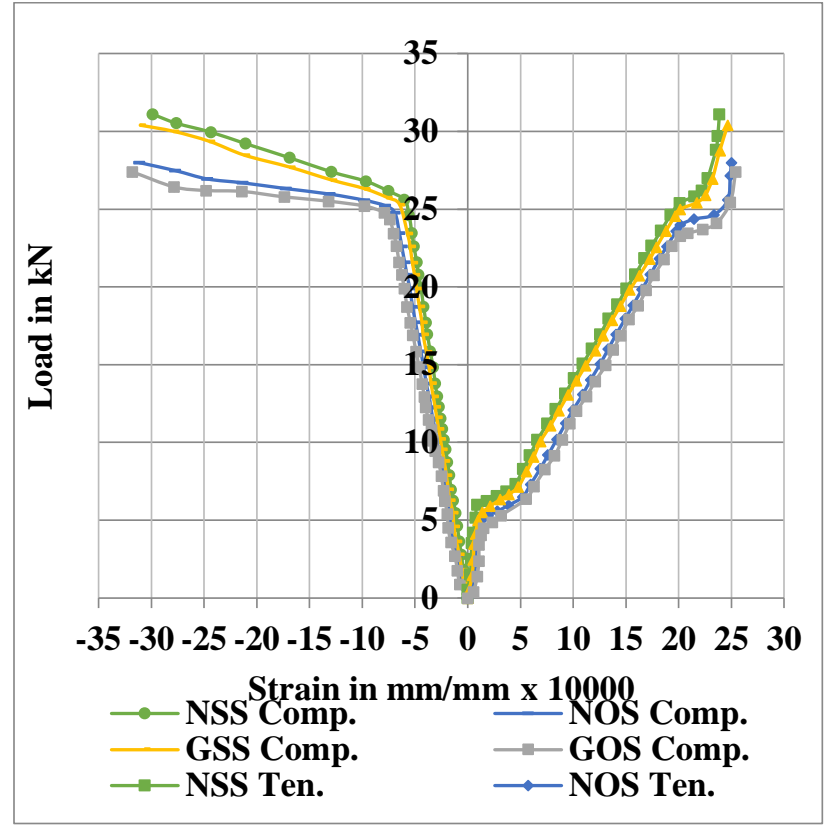

(a)

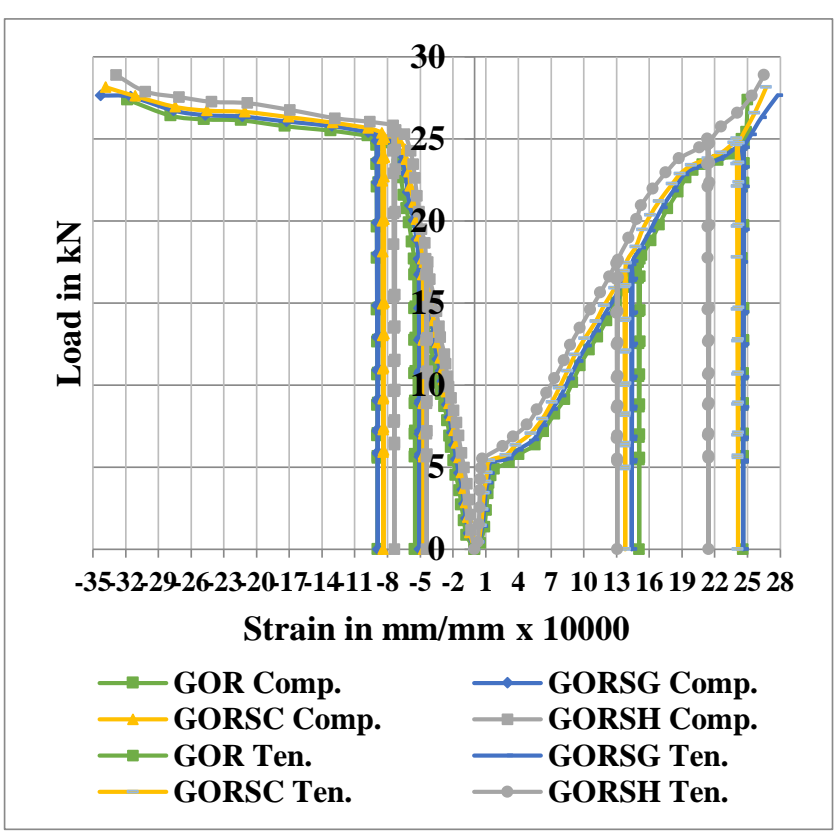

(b)

Figure 4. Load strain response: (a) group one

(b) group two

\subsection{Crack Pattern and Mode of Failure}

Table (9) shows a comparison between the proposed specimens within the two groups with respect to crack width. In the first group, the mode of failure of all normal and Geopolymer beams within this group was flexural failure mode. The crack width at first cracking load by $22.58 \%, 12.9 \%$ and $35.48 \%$ for NOS, GSS and GOS respectively if compared with NSS specimen. On the other hand, the cracking width at yielding is also increased by $16 \%, 12 \%$ and $36 \%$ for the same specimens sequence above. This behavior can be attributed to the crack path deviation in the zone around the web opening in the holed beams which results in increasing the crack width and length. Moreover, the Geopolymer beams illustrate cracking width level more than normal concrete for both solid and holed beams which can be ascribed to the difference in tensile strength. However, further research is needed to correlate the crack width versus the relevant tensile strength in reinforced Geopolymer concrete beams.

Within the second group. The mode of failure of un strengthened Geopolymer beam GOR was "flexural failure" while other specimens (GORSG, GORSC and GORSH) within this group was "flexural shear failure" mode as shown in Fig. (5). such change in failure mode can be attributed to the relevant stiffening and ductility effects of the proposed FRP materials. The crack width at first cracking decreased load by $6.38 \%, 14.63 \%$ and $19.14 \%$ for GORSG, GORSC and GORSH if compared with GOR (un strengthened specimen). In addition, the cracking width at yielding is also decreased by $7.32 \%$, $14.63 \%$ and $17.07 \%$ for the same specimens sequence above. Fig. (6) shows the cracking patterns of the specimens for both groups.

Table 9. Cracking width for both groups

\begin{tabular}{ccccc}
\hline \multicolumn{4}{c}{ Group one } \\
\hline $\begin{array}{c}\text { Beam } \\
\text { designation }\end{array}$ & NSS & NOS & GSS & GOS \\
\hline $\begin{array}{c}\text { Crack width at } \\
\mathrm{P}_{\mathrm{cr}}(\mathrm{mm})\end{array}$ & 0.031 & 0.038 & 0.035 & 0.042 \\
\hline
\end{tabular}




\begin{tabular}{|c|c|c|c|c|}
\hline $\begin{array}{l}\text { Increasing the } \\
\text { crack width at } \\
\mathrm{P}_{\mathrm{cr}} \%\end{array}$ & I & 22.58 & 12.9 & 35.48 \\
\hline $\begin{array}{l}\text { Crack width at } \\
P_{\mathrm{y}}(\mathrm{mm})\end{array}$ & 0.25 & 0.29 & 0.28 & 0.34 \\
\hline $\begin{array}{l}\text { Increasing the } \\
\text { crack width at } \\
\text { Py } \%\end{array}$ & I & 16 & 12 & 36 \\
\hline \multicolumn{5}{|c|}{ Group two } \\
\hline $\begin{array}{c}\text { Beam } \\
\text { designation }\end{array}$ & GOR & GORSG & GORSC & GORSH \\
\hline $\begin{array}{l}\text { Crack width at } \\
\mathrm{P}_{\text {cr }}(\mathrm{mm})\end{array}$ & 0.047 & 0.044 & 0.041 & 0.038 \\
\hline $\begin{array}{l}\text { Increasing the } \\
\text { crack width at } \\
\quad \mathrm{P}_{\mathrm{cr}} \%\end{array}$ & / & 6.38 & 14.63 & 19.14 \\
\hline $\begin{array}{l}\text { Crack width at } \\
P_{\mathrm{y}}(\mathrm{mm})\end{array}$ & 0.41 & 0.38 & 0.35 & 0.34 \\
\hline $\begin{array}{l}\text { Increasing the } \\
\text { crack width at } \\
\text { Py } \%\end{array}$ & / & 7.32 & 14.63 & 17.07 \\
\hline
\end{tabular}
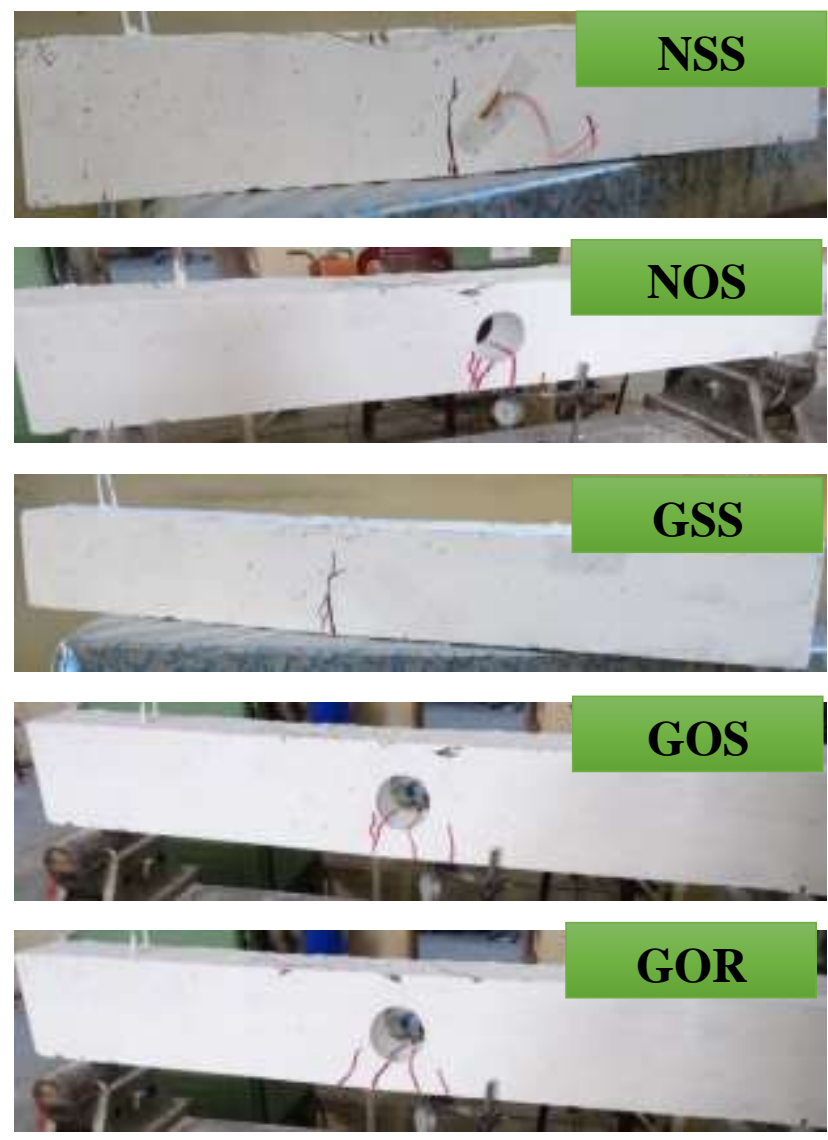
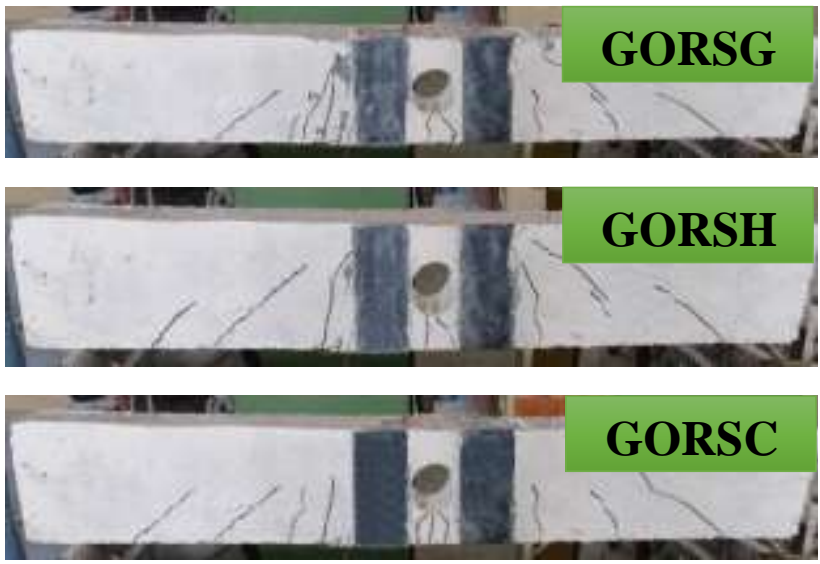

Figure 5. The cracking pattern for the two groups

\section{Conclusions}

The following are the main conclusions that can be evaluated during the current study:

1. The presence of "large web opening" affects the relevant flexural rigidity for both normal and Geopolymer concrete.

2. The first cracking load of beams with opening is less than that of solid beams for both normal and Geopolymer concrete.

3. The FRP strengthening for Geopolymer reinforced concrete beams "with web opening" can enhance the flexural behavior depending upon the mechanical potential of the used material.

4. The FRP strengthening "by vertical strips" may change the mode of failure from "flexural" to "shear flexural".

5. The FRP strengthening of Geopolymer beams with opening enhances the consequent first cracking, stiffness and ultimate load depending upon the mechanical potential of the used material.

6. The Hybrid (CFRP+FRP) strengthening of Geopolymer beams with opening enhances the consequent first cracking, stiffness and 
ultimate load more than Hybrid and GFRP strips.

7. The GFRP strips give deflection levels more than Hybrid and CFRP due to its ductile nature.

8. The strain levels confirms the supremacy between the proposed specimens for both Geopolymer and normal concrete. However, this study could use as a guide to developing awareness in the field of strengthening Geopolymer RC beam under different fashions and distributions of FRP materials.

\section{Acknowledgement}

The author thanks Mustansiriyah University, which provides all facilities and scientific support (by giving an opportunity for its users to use the available scientific references in its libraries and use of the internet unit, etc.), but the authors no receive financial support from Mustansiriyah University, agency, and other sectors.

\section{Conflict of Interest}

The authors declare that there are no conflicts of interest regarding the publication of this manuscript.

\section{Abbreviations}

$\begin{array}{cc}\text { Abbreviation } & \text { Description } \\ \text { RC } & \text { Reinforced Concrete } \\ \text { CFRP } & \text { Carbon Fiber Polymer } \\ \text { GFRP } & \text { Glass Fiber Polymer } \\ \mathrm{P}_{\mathrm{cr}} & \text { Cracking load } \\ \mathrm{P}_{\mathrm{y}} & \text { Yielding load } \\ \mathrm{P}_{\mathrm{u}} & \text { Ultimate load } \\ \Delta_{\mathrm{y}} & \text { Yielding deflection } \\ \Delta_{\mathrm{u}} & \text { Ultimate deflection }\end{array}$

\section{References}

1. Ibrahem, A.M and Wahab, A.A. (2008). "Effect of temperature on the pozzolanic properties of metakaolin produced from iraqi kaolin clay". AL- Fatih Journal, Diyala University, Iraq. Vol. 4. No. 32, pp. 268-285.

2. Shah, S.P. and Wang, K. (2004). "Development of green cement for sustainable concrete using cement kiln dust and fly ash". International Workshop on Sustainable Development and Concrete Technology.

3. Hadi, N. A. (2016). "Experimental behavior of hybrid steel-polypropylene fiber reinforced concrete deep beam containing openings". MSc. Thesis. Building and Construction Engineering Department, University of Technology, Baghdad, Iraq.

4. Khale, D. and Chaudhary, R. (2007). "Mechanism of geopolymerization and factors influencing its development: a review". Journal of materials science. Vol. 42, pp. 729-746.

5. Hasan, A. S. (2016). "Structural behavior of self-compacting reinforced concrete deep beams containing openings". MSc. Thesis. Building and Construction Engineering Department, University of Technology. Baghdad, Iraq.

6. Abdul-Razzaq, K.S., Ali, H.I. and AbdulKareem, M.M. (2017). "A new strengthening technique for deep beam openings using steel plates". International Journal of Applied Engineering Research. Vol. 12. No.24, pp. 15935-15947.

7. Prentzas, E. G. (1968). "Behavior and reinforcement of concrete beams with large rectangular apertures". Ph.D. Thesis. University of Sheffield, UK.

8. Jabbar, S., Hejazi, F. \& Mahmod, H.M. (2016). "Effect of an opening on reinforced 
concrete hollow beam web under torsional, flexural, and cyclic loadings". Latin American Journal of Solids and Structures. Vol. 13, pp. 1576-1595.

9. Mansur MA, Tan KH, Weng W. (2001). "Effects of creating an opening in existing beams". ACI Structural Journal. Vol 98. No. 6, pp. 407-415.

10. Ahmed, A., Fayyadh, M. M., Naganathan, S., \& Nasharuddin, K. (2012). "Reinforced concrete beams with web openings: A state of the art review". Materials \& Design. Vol. 40. pp. 90-102.

11. Mansur MA, Tan KH. (1999). "Concrete beams with openings: analysis and design". CRC Press LLC. Boca Raton. Florida. USA.

12. Mansur MA. (1998). "Effect of openings on the behavior and strength of RC beams in shear". Cement and Concrete Composites. Vol. 20. No. 6, pp.477-486.

13. Tan, K.H., Mansur, M.A. and Wei, W. (2001). "Design of reinforced concrete beams with circular openings". Structural Journal. Vol. 98, No. 3, pp. 407-415.

14. Chin, S.C., Shafiq, N. and Nuruddin, M.F. (2015). "FRP as strengthening material for Reinforced Concrete beams with openingsA review". KSCE Journal of Civil Engineering. Vol. 19, pp. 213-219.

15. Aykac, B., Aykac, S., Kalkan, I., Dundar, B. and Can, H. (2015). "Flexural Behavior and Strength of Reinforced Concrete Beams with Multiple Transverse Openings". ACI Structural Journal. Vol. 111 No. 2, pp. 267277.

16. Yang K.H., Ashour A.F. (2007). "Structural behaviour of reinforced-concrete continuous deep beams with web openings". Magazine of Concrete Research. Vol. 59, No. 10, pp. 699-71.
17. Imam, M., Tahwia, S., Elagamy A., and Yousef, M. (2004). "Behavior of reinforced concrete beams strengthened with carbon fiber strips", Egypt.

18. Al-Amery, R. and Al-Mahaidi, R. (2005). "Coupled flexural-shear retrofitting of $R C$ beams using CFRP straps". The $13^{\text {th }}$ International Conference of Composite Structures. Melbourne, Australia, www.elsevier.com.

19. Grace, N.F., and Grace, M. (2005). "Effect of repeated loading and long term humidity exposure on flexural response of cfrp strengthened concrete beams". Proceedings of the International Symposium on Bond Behaviour of FRP in Structures.

20. Dash, N. (2009). "Strengthening Of reinforced concrete beams using glass fiber reinforced polymer composites". Msc. Thesis. Civil Engineering Department, National Institute of Technology, Rourkela.

21. H. R. Sobuz, E. Ahmed, N. M. S. Hasan and M. A. Uddin. (2011). "Use of carbon fiber laminates for strengthening reinforced concrete beams in bending". International Journal of Civil and Structural Engineering. Vol 2. Pp.67 - 84 .

22. Önal, M. M. (2014). "Strengthening reinforced concrete beams with CFRP and GFRP". Advances in Materials Science and Engineering, pp. 1-8.

23. Kadhim, A. M. H., Numan, H. A., \& Özakça, M. (2019). "Flexural strengthening and rehabilitation of reinforced concrete beam using BFRP composites: finite element approach". Advances in Civil Engineering, pp. 1-17.

24. Abdalla, H.A., Torkey, A.M., Haggag H.A. and Abu-Amira, A.F. (2003). "Design against cracking at openings in reinforced concrete beams strengthened with composite 
sheets", Composite Structures. Vol. 60, No. 2, pp. 197-204.

25. Chin, S.C., N. Shafiq and Nuruddin M.F. (2012). "Strengthening of $R C$ beams with large openings in shear by CFRP laminates: $2 D$ nonlinear FE analysis". World Academy of Science, Engineering and Technology. Vol. 62, pp. 549 - 554.

26. Chakrasali, V., and Abdulla, S. (2015). "Shear and flexural behaviour of r.c.c. beam with circular opening strengthened by CFRP sheets". Int. Journal of Engineering Research and Applications. Vol. 5, No 4, pp.101-104.

27. Nie, X.F., Zhang, S.S., Yu, T. (2020). "Behaviour of RC beams with a fibrereinforced polymer (FRP)-strengthened web opening", Composite Structures. Vol. 252, No.15, 112684,

28. Iraqi Specifications No. (5). (1984). "Portland cement". Baghdad, Iraq: Iraqi Central Organization for Standardization and Quality Control.
29. Iraqi specification No.45/1984, "Aggregate from natural sources for concrete", Central Agency for Standardization and Quality Control, Planning Council, Baghdad, Iraq.

30. AbdulMajeed Allawi, A., and Nadhom Shubber, A. (2018). "Response of laced reinforced concrete beams subjected to repeated loading". Journal of Engineering and Sustainable Development. Vol. 22, No. 1.pp. 172-184.

31. Shah, S.P. and Wang, K. (2004) "Development of green cement for sustainable concrete using cement kiln dust and fly ash" International Workshop on Sustainable Development and Concrete, Technology, Beijing, China. 